\title{
Biodiversity and the built environment: Implications for the Sustainable Development Goals (SDGs)
}

\author{
Alex Opoku \\ UCL Bartlett School of Construction \& Project Management, University College London
}

\begin{abstract}
Recent major global environmental initiatives toward a more sustainable society are the Sustainable Development Goals (SDGs), the New Urban Agenda (NUA) and the Paris Agreement. The built environment has been recognised as a major contributor to loss of biodiversity and should therefore play a major role in a sustainable world where ecological values are enhanced. There should be a smooth interaction between the built environment and the natural environment because humanity and nature are the usual victims of loss of biodiversity. The purpose of this paper is to examine the link between the Built Environment, Biodiversity and the Sustainable Development Goals. The paper explores the role of a sustainable built environment towards biodiversity conservation which is central to the realisation of the SDGs in general and SDG 15 in particular. The paper adopts a qualitative research methodology using knowledge generation workshop involving 16 experts from both academia and industry. The results show that, even though the built environment has a negative impact on biodiversity, it also has the greatest opportunity to integrate biodiversity into all development projects. Reducing the impact of the built environment on biodiversity should be an integral part of policies and strategies towards a sustainable built environment. All key built environment stakeholders need to engage in raising awareness of the effects of biodiversity loss as a result of construction activities, on the health and wellbeing of mankind. The value of this paper is to help decision-makers such as government agencies, industryplayers and non-governmental organisations to understand the contributions of the built environment towards biodiversity conservation in achieving the SDGs.
\end{abstract}

Keywords: Biodiversity; Built environment; Construction industry; Sustainable development goals; SDG 15 


\section{Introduction}

The construction industry is described as the least sustainable industry globally consuming almost half of the non-renewable resources used. Lundholm (2006) argues that the built environment has a severe impact on the natural ecosystems due to the amount of energy and materials needed to sustain the sector. It is also important to note that, human activities in the built environment do contribute to loss of biodiversity affecting the ability of the ecosystem to support living organism (Zari, 2012). The natural and built environments are interdependent and the interaction has significant impact on the planet. A good functioning ecosystem is needed to sustain life on the planet and biodiversity is an important part of this process (UK Green Building Council, 2009; Willmott Dixon, 2010). The United Nations Convention on Biological Diversity defines Biodiversity (Biological Diversity) as "the variability among living organisms from all sources including, inter alia, terrestrial, marine and other aquatic ecosystems and the ecological complexes of which they are part; this includes diversity within species, between species and of ecosystems" (UN, 1992:3). The term Biodiversity describes all living things such as plants, animals, fungi, and micro-organisms and the variations within or between species and the ecosystems.

The Built Environment rarely considers the connection between the biodiversity and human wellbeing when delivering infrastructure and housing projects; little attention is paid to the integration of the relevant biodiversity strategies for sustainable urban development (Edwards, 2010). Despite the negative impact of the built environment on biodiversity, the delivery of new construction projects or the refurbishment of existing built assets have the opportunity to enhance the ecological value of most construction sites (UK Green Building Council, 2009). The preservation of biodiversity in a sustainable built environment with little or no natural habitat could help the drive to reduce loss of biodiversity without concentrating on unharmed natural habitats (Alvey, 2006). Preserving and enhancing biodiversity through the design and the management of sustainable urban environment requires the consideration of both the ecological and the human requirements and use (Aronson et al., 2017).

The built environment is described as a major contributor to biodiversity loss and climate change due to the large volume of resources consumed by the construction industry. It is therefore argued that, the built environment can significantly contribution to the solutions addressing the problem of biodiversity loss (Zari, 2012). The built environment presents a serious threat to the protection of biodiversity if an urgent action towards a more sustainable built environment across the globe is not implemented. The universal adoption of the 2030 
agenda for Sustainable Development which set out 17 Sustainable Development Goals and 169 targets, underpinned by 232 indicators is one major initiative towards the protection of the planet for current and future generations (UN, 2015). Sustainable Development Goal 15 (SDG15) aims at "protecting, restoring and promoting sustainable use of terrestrial ecosystems, sustainably manage forests, combat desertification, and halt and reverse land degradation and biodiversity loss" (UN, 2015). A built environment that supports good health and wellbeing is underpinned by better biodiversity (Nolan et al., 2009). The built environment provides value for biodiversity when considering the conservation and enhancement of nature as the integral part of all proposals for new developments or regeneration projects. The built environment presents good opportunities for promoting wildlife and enhanced biodiversity by greening the urban environment. This can be achieved at optimal cost when properly embedded throughout the whole project delivery process. A sustainable built environment fully developed with living walls, green roofs and green space could enhance the quality of public health.

This paper is novel and timely due to the importance of the SDGs in addressing the global challenges such climate change, hunger, health, education, poverty, energy etc. The paper therefore addresses the following research questions;

- What is the link between the built environment, biodiversity and the SDGs?

- How can the built environment conserve and restore biodiversity as part of urban development?

- What role can a sustainable built environment play towards the realisation of the SDGs?

The study contributes to the understanding of the link between the built environment, biodiversity and the SDGs; providing the opportunity for the relevant industry stakeholders and policy-makers to put biodiversity at the heart of policies and strategies driving the sustainable development goals. This paper identifies construction industry best practices and approaches that support the restoration of biodiversity in the built environment towards the attainment of the SDGs. The rest of the paper is structured as follows; Section 2 presents literature review on biodiversity and the built environment, urban development and biodiversity, value of biodiversity integrated built environment, construction activities on biodiversity and how biodiversity can be preserved through a sustainable built environment. Section 3 describes the adopted methodology using participatory knowledge production 
workshop as qualitative data collection method. Section 4 discusses the research results whiles the final section 5 draws the conclusions from the study.

\section{Literature review}

\subsection{The sustainable development goals and biodiversity}

The agenda towards global conservation of biodiversity was agreed in June 1992 at the Convention of Biological Diversity, the Earth Summit in Rio de Janeiro (the 'Rio Convention') (UN, 1992). However, the 2030 agenda for Sustainable Development provides the framework of universal goals and targets aim at addressing the challenges faced by society today. Biodiversity underpins the ecosystem services that are essential for human wellbeing and economic activities supporting the achievement of the Sustainable Development Goals (UNECE, 2018). It is however important to know that the protection of biodiversity is highly embedded across most of the SDGs. The incorporating of biodiversity into the development of the built environment is key for the achievement of the Sustainable Development Goals; SDG 15 has high impact on SDG 3 (Good health and wellbeing), SDG 6 (Clean water and sanitation), SDG 11 (Sustainable cities and communities), SDG 12 (Sustainable consumption and production), SDG 13 (Climate action) and SDG 15 (Biodiversity-Life on land) (UNDP, 2016).

The Sustainable Development Goal 15 mainly focuses on the preservation and the sustainable use of the ecosystems and species on the planet. Humanity greatly depends on biodiversity for survival and enhanced quality of life. However, human activities such as the over consumption of natural resources is having increasing pressure on biodiversity due to continuous urban development. Table 1 presents the UN global target for the SDG 15 that should be achieved by 2030 (UN, 2015). The interlinked and interwoven nature of the SDG 15 and the other SDGs is for example shown in SDG 15 target 15.9 which is relevant to SDG 1(End poverty in all its forms everywhere) (UNDP, 2016). The SDGs are aimed at delivering a prosperous society that provides justice and dignity for people whiles protecting the planet over the next 15 years (2015-2030). 


\begin{tabular}{|c|l|}
\hline 15.1 & $\begin{array}{l}\text { Ensure the conservation, restoration and sustainable use of terrestrial and inland } \\
\text { freshwater ecosystems, forests, wetlands, mountains and drylands by } 2020\end{array}$ \\
\hline 15.2 & $\begin{array}{l}\text { Promote the implementation of sustainable management of all types of forests, halt } \\
\text { deforestation, restore degraded forests and substantially increase afforestation and } \\
\text { reforestation globally by 2020 }\end{array}$ \\
\hline 15.3 & $\begin{array}{l}\text { Combat desertification, restore degraded land and soil, including land } \\
\text { affected by desertification, drought and floods, and strive to achieve a land } \\
\text { degradation-neutral world by 2030 }\end{array}$ \\
\hline 15.4 & $\begin{array}{l}\text { Ensure the conservation of mountain ecosystems, including their biodiversity, in order to } \\
\text { enhance their capacity to provide benefits that are essential for sustainable development } \\
\text { by 2030 }\end{array}$ \\
\hline 15.5 & $\begin{array}{l}\text { Take urgent and significant action to reduce the degradation of natural habitats, halt the } \\
\text { loss of biodiversity and, by 2020, protect and prevent the extinction of threatened species }\end{array}$ \\
\hline 15.6 & $\begin{array}{l}\text { Promote fair and equitable sharing of the benefits arising from the utilization of genetic } \\
\text { resources and promote appropriate access to such resources, as internationally agreed }\end{array}$ \\
\hline 15.7 & $\begin{array}{l}\text { Take urgent action to end poaching and trafficking of protected species of flora and } \\
\text { fauna and address both demand and supply of illegal wildlife products }\end{array}$ \\
\hline 15.8 & $\begin{array}{l}\text { Introduce measures to prevent and significantly reduce the impact of invasive alien } \\
\text { species on land and water ecosystems and control or eradicate the priority species by } \\
\text { 2020 }\end{array}$ \\
\hline 15.9 & $\begin{array}{l}\text { Integrate ecosystem and biodiversity values into national and local planning, } \\
\text { development processes, poverty reduction strategies and accounts by 2020 }\end{array}$ \\
\hline & \\
\hline
\end{tabular}

Source: (UN, 2015)

\subsection{Understanding biodiversity and the built environment}

Biodiversity is affected by the built environment resulting in fragmentation and loss of habitat (Antrop, 2000; McKinney, 2002). The built environment can play a critical role in supporting biodiversity; the provision of green urban spaces in the built environment is essential for the support of biodiversity and also provides the opportunity for people to connect with nature (Firth et al., 2014; Lepczyk et al., 2017). The ecosystem and biodiversity are essential part of the urban environment contributing to environmental resilience against disaster resulting in an improved quality of life. It is argued that an integrated approach to sustainable built environment leads to a general quality of life (SIDA, 2016). Biodiversity offers social, economic and environmental benefits beyond the protection of habitat and species. Biodiversity conservation should aim at reinstating and enhancing the population of species and habitats now and the future.

In 2011, the United Nations declared a Decade on Biodiversity (2011-2020) with a global ten-year framework of action to be adopted by all countries and all stakeholders. The strategic plan was to understand the primary causes of loss of biodiversity and to ensure that 
governments and industry consider the impact of all decisions on biodiversity (UNEP, 2011). As a result of this global strategy, the UK government developed its own strategy towards the protection of biodiversity as set out in the "UK Biodiversity 2020" strategy which is aimed at halting the overall loss of biodiversity to ensure healthy well-functioning ecosystems that benefit both mankind and wildlife. The strategy seeks to protect and improve the natural environment as fundamental objectives of the UK planning system (DEFRA, 2011). The destruction of valuable habitat during urban development process requires strategic management use of habitat replication techniques to ensure the achievement of the sustainable development goals (Donovan et al., 2005). The provision of urban green space for biodiversity conservation due to fragmented natural environment caused by global urban development is essential for sustainable development (Goddard et al., 2010).

\subsubsection{Urban development and biodiversity}

The built environment in general and the construction industry in particular has a vital role to play in preserving biodiversity, but this is usually not a priority area in the construction industry. The construction industry can therefore lead the agenda towards the integration of biodiversity at the heart of sustainable development. The impact of the built environment on the biodiversity causes climate change as a result of the destruction of land cover for construction (Gitay et al., 2002; Zari, 2012). However, biodiversity should be incorporated into the built environment by providing green urban spaces such as green roofs that can contribute to urban biodiversity conservation (Lepczyk et al., 2017). The integration of biodiversity into new development project should be a central part of the planning application process. Biodiversity exists in a built environment along waterways, parks, street plantings, gardens and empty lots.

The biodiversity value of new development and the refurbishment of projects should be assessed and establish a strategy for enhancing the biodiversity of the project site with the aim of improving the quality of life. It is important that a good balance between the human and the natural environment is established in all urban developments. AECOM (2011) developed a planning tool (The Index of Biodiversity Potential-IBP) for assessing the potential for urban development projects to support biodiversity. The UK Green Building Council (2009) believes that the construction and property sector lacks a good understanding of the impact of urban development on biodiversity and how this could be enhanced through sustainable design, construction and management of built assets. The process of how 
development projects are design, procure and build impact greatly on biodiversity which is vital for the wellbeing of current and future generation.

\subsubsection{The value of biodiversity integrated built environment}

The built environment sector should promote construction practices that preserve more natural vegetation during construction; this can be achieved with city planning systems that enhance the preservation of biodiversity (McKinney, 2002). New development projects in the built environment should integrate biodiversity schemes such as the creation of habitats for wildlife by providing nest boxes, living roofs and landscapes. These biodiversity schemes should not add excessive cost to the overall construction project budget. Providing biodiversity close to people in an urban environment provide positive environmental benefits such as the absorption of the atmospheric pollutants and air cooling (CABE, 2006). A built environment with well integrated biodiversity enhance the wellbeing of the people who live and work in urban areas; as well as the potential to offer diversity of ecosystem services (Rebele, 1994). Integrating biodiversity into the planning, management and the legislation process of our cities and key infrastructure is essential towards the solutions to promote biodiversity (SIDA, 2006). A new biodiversity paradigm towards a sustainable built environment that embraces biodiversity as an integral part of the design and the delivery of built environment should be adopted. Delivering ecological design that balances the built and natural environments in urban development is essential but built environment professionals hardly understand the relation between biodiversity and human wellbeing (Brown and Grant, 2005).

The built environment and biodiversity interact in many ways; both directly and indirectly. Planning systems in the built environment should therefore integrate biodiversity in new development projects; this should be aimed at protecting existing wildlife sites and providing more green spaces in an urban environment (McKinney, 2002). Biodiversity conservation in an urban environment provides aesthetic, cultural and economic value to society. Puppim de Oliveira et al. (2011) add that the built environment should integrate ecological knowledge into urban planning systems to reduce loss of biodiversity and the habitat. Planning for a built environment with biodiversity should aim at protecting and enhancing existing resources in the habitat whiles seeking to provide good opportunities for the built environment to interact positively with nature. 


\subsection{Construction industry activities on biodiversity}

The construction industry has a significant role in reducing loss of biodiversity since all sorts of construction projects from major infrastructure projects to small housing projects have the potential to cause loss of natural habitats (Woodall and Crowhurst, 2003). The built environment impacts on wildlife and ecological networks negatively at both the construction and the in-use stages of the project lifecycle. The global problem of biodiversity loss is critical for the international community considering how biodiversity has featured in all the major global initiatives to combat environmental issues (Bastian et al., 2012). The international community's desire to end poverty and ensure prosperity for all cannot be achieved without the protection of the environment. Construction activities negatively impact on endangered species on construction sites and adjacent areas. For example transport infrastructure projects have the potential to destroy large areas of natural habitat since such projects form a large network of infrastructure affecting both local and national biodiversity. The extinction of endangered species due to loss of biodiversity cannot be reversed and therefore every effort should be put in place to prevent it from happening (Zari, 2012).

The man-made systems of the environment, such as the buildings and infrastructure (transportation, telecommunications, energy, water and waste systems) affect biodiversity (Nolan et al., 2009). Increasing urbanisation has exposed plant species and animals due to the loss habitat (Karuppannan et al., 2014). Environmental issues should be considered at the front-end of the project cycle to minimise the negative impact of construction activities on the environment. Land loss as a result of urbanisation affects the natural ecosystems and this is a major global problem (Barrico and Castro, 2016). It is believed that urban development alone accounts for 35 percent of the loss of scarce plant species in the counties surrounding urbanized areas in the United Kingdom. This shows that the impact of urbanisation on biodiversity is severe than other forms of human activities (Czech et al., 2000). The demand for large volumes of natural resources such as timber and fossil fuels for construction activities is destroying large areas of habitat causing loss of biodiversity (Fahrig, 2001). Again mineral extraction for use in the construction industry affects biodiversity; the industry should carefully consider the source of all materials used in construction. Another approach is to conserve and rehabilitate existing built assets instead of demolishing and building new projects.

Ogden (2014) argues that biodiversity is connected with all the sustainable building criteria (energy, water, health and wellbeing etc.) and therefore biodiversity schemes should go beyond setting aside natural habitat to include community education about the built asset and 
the conserved environment during the in-use/occupancy stage of the project. Loss of biodiversity due to construction activities do not just affect plants and animals only but also the ecosystem's ability to protect built assets from floods, landslides and wildfire caused by the effects of climate change (Brook et al., 2008; Zari, 2012). In most cases urban development project processes do not fully consider the needs of wildlife on proposed construction sites, destroying valuable habitat that may be home for endangered species. Light and noise pollution as a result of urbanisation is believed to affect the physiology, behaviour and reproduction of many animals (Newport et al., 2014). Biodiversity considerations seem to be one of the least priorities when assessing new development project. The UK construction industry developed a set of biodiversity indicators that allow the impact of construction activities on biodiversity to be measured (Woodall and Crowhurst, 2003).

Biodiversity as an integral part of the built environment is beneficial to individuals, businesses and communities since a healthy and functional natural environment is essential for the drive for a sustainable economic growth. A case study research by Karuppannan et al. (2014) on Urban Green Space and Urban Biodiversity in Kuala Lumpur, Malaysia revealed that, there is a strong relationship between green open spaces in urban development and peoples' mental and physical wellbeing. Lepczyk et al (2017) add that biodiversity benefits human health and wellbeing when incorporated into urban development plans.

\subsection{Preserving biodiversity through sustainable built environment}

The built environment as a primary habitat for people drives biodiversity loss but also has the potential to mitigate the causes of such loss (Zari, 2012). Sustainable built environment provides opportunities to protect and improve the natural environment; all urban development projects should have biodiversity strategy aimed at enhancing the interaction between the natural and built environment. McGranahan et al. (2005: 807) describe the Urban Environment as consisting of "large areas of parks, playgrounds, vacant plots, road-sides, street plantings, residential backyards, community and botanical gardens, and sports grounds". The creation of biodiversity enhanced schemes with green areas for small trees and shrubs or green roof and walls as integral part of urban development projects; such green spaces form ecological networks for some birds and insects (EMBO, 2007). A built environment incorporated with trees improves the visualisation of the environment and more importantly providing habitat for animals and minimising air pollution. Where space is a 
problem, green roofs and green walls can still offer the opportunity to incorporate nature on new urban development. It's been argued that construction industry professionals lack a good understanding of the use of good urban design as a means of enhancing biodiversity (UK Green Building Council, 2009).

Apart from considering biodiversity in new development projects, it is also important that the management of existing built assets should consider wildlife. Greening the built environment with new habitats such as urban parks, woodlots, ecological landscaping, artificial nest sites and Sustainable Urban Drainage Systems (SUDS) can improve biodiversity (Alvey, 2006). The loss of biodiversity as a result of the built environment requires innovative schemes that can preserve and restore biodiversity in urban environment. The design of the urban environment should aim at supporting the local environment with a thriving ecosystem instead of the one that destroys the ecosystem; however this requires a fundamental shift in urban planning and design (Reed, 2007; Cole, 2012). Designing biodiversity into urban development projects through the provision of appropriate living environment for native and threatened species of plants and animals should be encouraged in a sustainable built environment. The construction of ecological corridors such as parks and waterways as integral part of urban development projects can enhance biodiversity and encourage species to inhabit such areas (EMBO, 2007). Urban development should contribute to the enhancement of biodiversity with a well-designed ecological landscape that creates habitats for plants and animals. Eco-friendly built environment designs should be the way forward in restoring biodiversity (Eisenstein, 2001). Biodiversity conservation can be achieved by properly managing green spaces that supports native plants and fauna (McKinney, 2002). A built environment integrated with biodiversity provides the opportunity for physical activities contributing to the quality of life. The development of green spaces such as green roof and walls in urban areas is good for biodiversity positively in terms of protected plant species and birds (Goddard et al., 2010; Aronson et al., 2014; Beninde et al., 2015; Lepczyk et al., 2017).

A study by Snep et al. (2006) on artificial environment and conservation programmes identified 90 species of birds on 25 sites examined in the Netherlands; this study therefore demonstrates the value of a sustainable built environment for biodiversity. Dunnett and Kingsbury (2004) add that delivering buildings with green roofs improves the visual environment, efficient energy use and retaining storm waters. Integrating biodiversity into the built environment benefit residents or end-users health and wellbeing; however these positive impacts are best realised when biodiversity is considered at the planning and design stages of 
the project development. Figure 1 illustrates how sustainable built environment can be engineered to reduce loss of biodiversity.

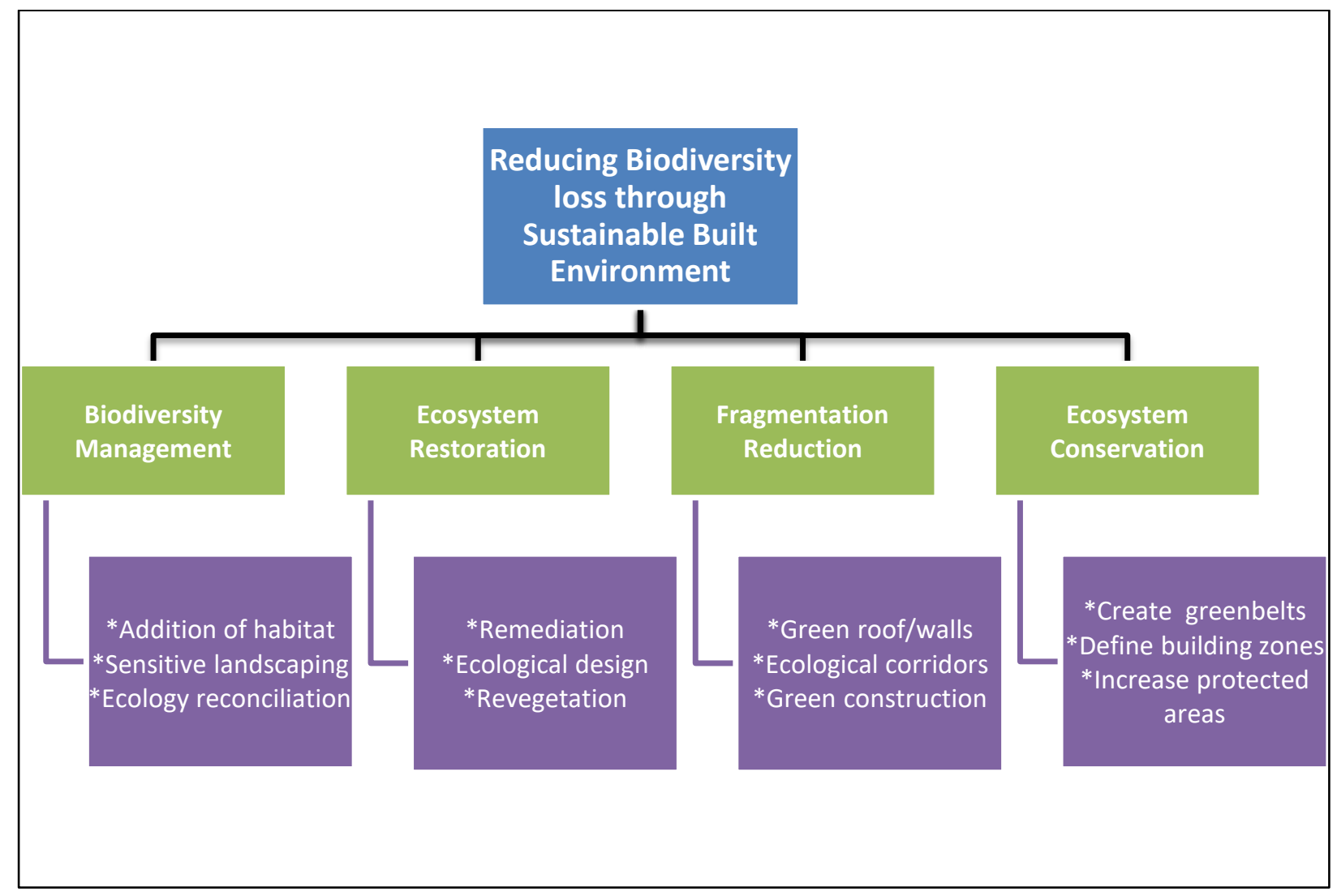

Figure 1 - Reducing Biodiversity loss through Sustainable Built Environment (adopted from Zari, 2014:6)

\section{Methodology}

The study adopts the constructivist philosophy that argues that reality can fully be understood only through the subjective interpretation and intervention in reality (Creswell, 2003). In the qualitative research paradigm, the most important focus is for researchers to capture accurately the existing experiences and perceptions of participants involved in the phenomenon or process under investigation (Onwuegbuzie and Johnson, 2006). Qualitative method is concerned with words and images out of which the researcher seeks to interpret meanings and explanations as to the way people behave and to develop an understanding of social constructs. This study therefore adopts a qualitative research approach for data collection and analysis. Qualitative data is collected through participatory research methodology reflecting and exploring the experiences of research participants (Swain and 
French, 2004) and support the involvement of research stakeholders in the knowledgeproduction process (Bergold, 2007). It is about conducting research with and for the research subjects; research with the people rather than on the people. Biodiversity, built environment and SDGs are people-centred and therefore the adoption of participatory research methodology where the research stakeholders participate in the co-production of knowledge with the purpose of understanding social reality from the people's perspectives is justified.

Qualitative data was collected through interactive focus group workshop consisting of four groups of four members each, facilitated by the researcher discussing the role of the built environment in achieving biodiversity which is at the core of the SDGs. The workshop aimed at obtaining detailed information, perceptions and opinions from participants on achieving the SDG 15 (Biodiversity) in particular. There were 9 academics and 7 practitioners from the UK construction industry selected through purposeful sampling. Invitations were sent to 20 potential participants but 16 accepted to take part in the study. Participants were selected on the basis of their knowledge and expertise in sustainable development and the built environment. The qualitative data from the participants were analysed, interpreting and providing an explanatory accounts through content analysis. A profile of the workshop participants are presented in Table 2. 
Table 2 - A profile of the knowledge creation workshop participants

\begin{tabular}{|c|c|c|c|c|c|c|}
\hline \multirow[b]{2}{*}{ 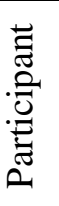 } & \multirow[b]{2}{*}{ Job Title } & \multicolumn{2}{|c|}{ Background } & \multicolumn{2}{|c|}{ Area of Expertise } & \multirow[b]{2}{*}{$\begin{array}{l}\text { Years of } \\
\text { experience }\end{array}$} \\
\hline & & Academic & Practitioner & $\begin{array}{l}\text { Sustainable } \\
\text { Development }\end{array}$ & $\begin{array}{l}\text { Built } \\
\text { Environment }\end{array}$ & \\
\hline A & Senior Lecturer & $\mathrm{x}$ & & & $\mathrm{x}$ & 26 \\
\hline $\mathrm{B}$ & Lecturer & $\mathrm{x}$ & & & $\mathrm{x}$ & 16 \\
\hline $\mathrm{C}$ & $\begin{array}{l}\text { Sustainability R\&D } \\
\text { Manager }\end{array}$ & & $\mathrm{x}$ & $\mathrm{x}$ & $\mathrm{x}$ & 10 \\
\hline $\mathrm{D}$ & Senior Lecture & $\mathrm{x}$ & & & $\mathrm{x}$ & 15 \\
\hline E & $\begin{array}{l}\text { Professor \& } \\
\text { Managing Director }\end{array}$ & $\mathrm{x}$ & & $\mathrm{X}$ & & 25 \\
\hline $\mathrm{F}$ & Project Director & & $\mathrm{x}$ & & $\mathrm{x}$ & 30 \\
\hline G & Researcher & $\mathrm{x}$ & & & $\mathrm{x}$ & 5 \\
\hline $\mathrm{H}$ & $\begin{array}{l}\text { Service } \\
\text { Performance } \\
\text { Analyst }\end{array}$ & & $\mathrm{x}$ & & $\mathrm{x}$ & 6 \\
\hline $\mathrm{I}$ & Lecturer & $\mathrm{x}$ & & $\mathrm{x}$ & $\mathrm{x}$ & 7 \\
\hline $\mathrm{J}$ & Project Surveyor & & $\mathrm{x}$ & & $\mathrm{x}$ & 5 \\
\hline K & $\begin{array}{l}\text { Professor of } \\
\text { construction project } \\
\text { management }\end{array}$ & $\mathrm{x}$ & & $\mathrm{x}$ & $\mathrm{x}$ & 35 \\
\hline $\mathrm{L}$ & Senior Lecturer & $\mathrm{x}$ & & $\mathrm{x}$ & $\mathrm{x}$ & 15 \\
\hline $\mathrm{M}$ & Director & & $\mathrm{x}$ & $\mathrm{x}$ & & 7 \\
\hline $\mathrm{N}$ & $\begin{array}{l}\text { Architectural } \\
\text { Technician }\end{array}$ & & $\mathrm{x}$ & $\mathrm{x}$ & & 4 \\
\hline $\mathrm{O}$ & Senior Lecturer & $\mathrm{x}$ & & $\mathrm{x}$ & & 18 \\
\hline $\mathrm{P}$ & $\begin{array}{l}\text { Sustainability } \\
\text { Director }\end{array}$ & & $\mathrm{x}$ & $\mathrm{x}$ & $\mathrm{x}$ & 12 \\
\hline
\end{tabular}

\section{Results and discussions}

The workshop participants discussed how the built environment could be used as a driver for preserving and promoting biodiversity which is crucial for the realisation of the SDGs. An enhanced biodiversity in the built environment could be a critical driver for the construction industry. A built environment designed, constructed, managed and controlled by human interactions with biodiversity should be the new approach if loss of biodiversity is to be reduced. A well designed and constructed built asset create habitats in which wild species flourish. It is argued that there is a good opportunity globally to address biodiversity loss through urban development since more than half of the urban development required by 2030 
is yet to be constructed; new urban development project should adopt sustainable construction practices to deliver low carbon building and green infrastructure.

The impact of materials used on all construction projects on biodiversity should be assessed; the embodied carbon of specified materials should be evaluated. Construction materials sourced from unapproved forest can affects locally protected species. For example, participants 'B, D, E, and M' all noted that, the built environment sector can contribute to the preservation of biodiversity through "sustainable procurement of building materials, ensuring that only Forest Stewardship Council (FSC) certified timber is used on all construction sites". The efficient and responsible use of materials for the built environment seems to be identified as a major area where the built environment can make positive impact in the fight against loss of biodiversity. Workshop participant ' $\mathrm{C}$ ' pointed out that, "Deforestation can be reduced by promoting more responsible sourcing of timber materials".

Edwards (2010) argues that Architects have an important role to play by considering biodiversity measures at the design stage of the development. A sustainably planned, designed and constructed built asset contribute to the quality of the built environment required for a positive human health and wellbeing. Participant 'I' commented on the "adoption of biomimicry design that adopts the natural vegetation to address loss of biodiversity". Construction industry professionals should be educated on the protection of habitat during construction by developing a management plan that addresses biodiversity conservation for development projects where there is evidence of significant biodiversity on the proposed development site (Schewenius et al., 2014). For example, ecological professionals could be used as trainers on biodiversity awareness to construction site workers. Noise from construction activities should be reduced as much as possible by programming high noise related activities at certain time of the year; avoiding such activities during birds breeding season.

This was supported by workshop participants ' $\mathrm{J}$ ' adding that "specialist advise should be sought, land for construction surveyed for wildlife inhabitants (such as bats, Geckos, insects etc.) and provide new or alternative habitats for these animals. More importantly is the awareness of breeding calendar or seasons when certain endangered species could be vulnerable". It is however important to note that Suitably Qualified Ecologist (SQE) should be appointed to ensure that design and the construction process comply with the relevant legislations before any construction activity takes place. Biodiversity assessment of construction sites should be undertaken for all proposed development projects to identify 
existing habitats and species at the planning stages of all new developments and evaluate the potential to improve the value of wildlife. The use of "Sustainable assessment tools such as BREEM and the Code of Sustainable Homes should be encouraged or enforced to manage the long term effects of construction activities on biodiversity" (Participant ' $\mathrm{H}$ ').

However Donovan et al. (2005) believe that, the built environment could be engineered to integrate habitat into built assets. Urban Planners should develop management plans with ecological perspective into new development projects providing opportunities for biodiversity protection (Alvey, 2006); corridors for biodiversity and urban green spaces should be important parts of urban developments (Vergnes et al., 2013). Even though achieving the successful implementation of planning policies that integrates ecological dimensions may face technical and political challenges in some parts of the world, support from political and organisation leadership at all levels is crucial in order for the SDGs to stand any chance of being realised by 2030. Workshop participant ' $\mathrm{N}$ ' argues that "Construction industry-wide sensitization on the effects of construction activities on biodiversity should be carried out involving the key industry stakeholders". Small but valuable habitats for wildlife such as ponds and rivers acting as ecological corridors should be protected during construction. Urban development projects can be used to enhance the ecological value of construction sites instead of destroying them. For example, construction sites and surrounding areas could be protected by planting tree species and leaving naturally occurring plants uncut for the benefit of wildlife. "The built environment should be providing infrastructure in areas of land degradation to halt desertification" -participant 'K', whiles "Solar energy can be installed in desert areas to power water pumps to irrigate reforestation programmes"-participant ' $\mathrm{F}$ '. Biodiversity management plan should be developed as part of the core business strategy for reporting, monitoring and the review of all business activities impacting on the environment.

\section{Conclusions}

The study aimed at examining the link between the Sustainable Built Environment and Biodiversity conservation which is at the heart of the Sustainable Development Goals. It explores the adoption of sustainable construction practices that enhance the preservation and the promotion of biodiversity as an integral part of the built environment. A built environment with incorporated biodiversity improves the planets ability to adapt to climate 
change, improves the quality of air, flood mitigation and the overall health and wellbeing of people in society. This will require political leadership at global and national levels in terms of policy direction and new legislation addressing the protection of biodiversity. Biodiversity policies and strategies should consider the best approaches on harnessing the interaction of the natural and the built environment for the benefits of human needs and existing wildlife.

The study clearly shows that the built environment has an important role to play in reducing loss of biodiversity through the design, construction and the maintenance of built assets. There is the need to enhance existing sustainability assessment tools to consider fully the impact of all construction activities on biodiversity. Biodiversity should not only be incorporated into new building and infrastructure projects but also in the management of existing built assets. The integration of biodiversity into the built environment could increase the economic value of development land, marketability of development projects on such land and more importantly an improved wellbeing of the occupants/end-users. Adopting sustainable procurement practices that only source timber that has been certified by the Forest Stewardship Council (FSC) for construction activities could contribute towards the protection of biodiversity and the realisation of the sustainable development goals. Biodiversity is at the centre of many economic activities and contribute greatly to human development and wellbeing. The paper therefore recommends the integration of biodiversity value into national and regional planning and development processes and strategies. Again, training and awareness programmes on the connection between biodiversity and the built environment should be delivered to all professionals across the construction industry. Finally, the results of the study show that, the construction industry as a sector has the opportunity to influence the realisation of the SDGs by formulating policies and regulatory frameworks that drive the adoption of sustainable construction practices in delivering a more sustainable built environment. It is however important to note that, the adoption of sustainable practices and processes that promotes biodiversity conservation of the built environment requires government policies and regulatory frameworks that can force the construction industry to act and adopt more sustainable business practices. This study impacts on both the academic and policy community since little or nothing has been written in literature that links these three issues together; this paper presents the detail linkages between the built environment, biodiversity and the realisation of the SDGs. 


\section{References}

AECOM (2011), Biodiversity in the Built Environment and the Index of Biodiversity Potential, London: Architecture, Engineering, Construction, Operations and Management

Alvey, A. A. (2006), Promoting and preserving biodiversity in the urban forest, Urban Forestry \& Urban Greening, 5(1),195-201

Antrop, M. (2000), Changing patterns in the urbanized countryside of Western Europe, Landscape Ecology, 15(3), 257-270

Aronson, M.F.J., Lepczyk, C.A., Evans, K.L., Goddard, M.A., Lerman, S.B., MacIvor, J.S., Nilon, C.H and Vargo, T. (2017), Biodiversity in the city: Key challenges for urban green space management, Frontiers in Ecology and the Environment, 15(1), 189-196

Barrico, L. and Castro, P. (2016), Urban Biodiversity and Cities' Sustainable Development, In: Castro P., Azeiteiro U., Bacelar-Nicolau P., Leal Filho W., Azul A. (eds) Biodiversity and Education for Sustainable Development, World Sustainability Series. Springer, Cham

Bastian, O., Haase, D. and Grunewald, K. (2012), Ecosystem properties, potentials and services: the EPPS conceptual framework and an urban application example. Ecological Indicators, 21(1)7-16

Beninde, J., Veith, M. and Hochkirch, A. (2015), Biodiversity in cities needs space: A metaanalysis of factors determining intra-urban biodiversity variation, Ecology Letters, 18 (1), 581-592.

Bergold, J. (2007), Participatory strategies in community psychology research-a short survey. In A. Bokszczanin (Ed.), Poland, Welcomes Community Psychology: Proceedings from the 6th European Conference on Community Psychology (pp.57-66). Opole: Opole University Press

Brook, B. W., Sodhi, N. S. and Bradshaw, C. J. A. (2008), Synergies among extinction drivers under global change, Trends in Ecology \& Evolution, 23(8), 453-460

Brown, C. and Grant, M. (2005), Biodiversity \& human health: What role for nature in healthy urban planning? Built Environment, 31 (4), 326-338.

Creswell, J. W. (2013), Research Design: Qualitative, Quantitative, and Mixed Method Approaches (4th edition). Thousand Oaks, CA: Sage

CABE (2006), Making Contracts Work for Wildlife: How to Encourage Biodiversity in Urban Parks, London: Commission for Architecture and the Built Environment (CABE)

Cole, R. J. (2012), Transitioning from green to regenerative design, Building Research \& Information, 40(1), 39-53

Czech, B, Krausman, P.R and Devers, P. K. (2000), Economic associations among causes of species endangerment in the United States, Biological Conservation, 50(1), 593-60 
DEFRA (2011), Biodiversity 2020: A strategy for England's Wildlife and Ecosystem Services, London: Department for Environment, Food and Rural Affairs (DEFRA)

Donovan, R.G., Sadler, J.P. and Bryson, J. R. (2005), Urban biodiversity and sustainable development, Proceedings of the Institution of Civil Engineers, Engineering Sustainability, 158 (2), 105-114

Dunnett, N. and Kingsbury, N. (2004), Planting Green Roofs and Living Walls, Portland, Oregon: Timber Press

Edwards, B. (2010), Biodiversity: the New Challenge for Architecture, available at: https://www.thenbs.com/knowledge/biodiversity-the-new-challenge-for-architecture, accessed September 2010, Accessed on 11/09/17

Eisenstein, W. (2001), Ecological design, urban places, and the culture of sustainability, SPUR Newsletter, September

EMBO (2007), The human impact on biological diversity, European Molecular Biology Organization (EMBO) Reports, 8 (4), 316-318

Fahrig, L. (2001), How Much Habitat is Enough? Biological Conservation, 100(1), 65-74

Firth, L. B., Schofield, M., White, F. J., Martin W. Skov, M.W. and Hawkins, S. J. (2014), Biodiversity in intertidal rock pools: Informing engineering criteria for artificial habitat enhancement in the built environment, Marine Environmental Research, 102 (1), 122-130

Gitay, H., Suárez, A., Watson, R. and Jon Dokken, D. (2002), Climate Change and Biodiversity, IPCC Technical Paper, IPCC

Goddard, M.A., Dougill, A. J and Benton, T. G. (2010), Scaling up from gardens: biodiversity conservation in urban environments, Trends in Ecology \& Evolution, 25 (2), 9098

Karuppannan,S., Mukrim B. Z., Sivam, A. and Daniels, C. B. (2014), Urban Green Space and Urban Biodiversity: Kuala Lumpur, Malaysia, Journal of Sustainable Development, 7 (1), 1-16

Lepczyk, C. A, Aronson, M.F.J., Evans, K. L., Goddard, M. A., Lerman, S.B., and MacIvor, J. S (2017), Biodiversity in the City: Fundamental Questions for Understanding the Ecology of Urban Green Spaces for Biodiversity Conservation, BioScience, 67(9), 799-807

Lundholm, J. T. (2006), Green roofs and facades: a habitat template approach, Urban Habitats, 4(1), 87-101

Mcgranahan, G., Marcotullio, P., Bai, X., Balk, D., Braga, T., Douglas, I., Elmqvist, T., Rees, W., Satterthwaite, D., Songsore, J. and Zlotnik, H. (2005), Urban Systems, In: Hassan, R., Scholes, R. \& Ash, N. (eds.) Ecosystems and Human Well-Being. Volume 1: Current State and Trends. Washington: Island Press / Millennium Ecosystem Assessment 
Mckinney, M. L. (2002), Urbanization, biodiversity, and conservation, Bioscience, 52(10), 883-890

Newton, J, Nicholson, B, Saunders, R. (2011), Working with wildlife: guidance for the construction industry, CIRIA C691

Newport, J., Shorthouse, D. J., Manning, A. D. (2014), The effects of light and noise from urban development on biodiversity: Implications for protected areas in Australia, Ecological Management \& Restoration , 15(3), 204-214

Nolan, G., Hamilton, M. and Brown, M. (2009), Comparing the Biodiversity Impacts of Building Materials, Architectural Science Review, 52(4), 261-269

Ogden, L. E. (2014), Does Green Building Come up Short in Considering Biodiversity? BioScience, 64(2), 83-89

Onwuegbuzie, A. J. and Johnson, R. B. (2006), The validity issue in Mixed Research, Research in the schools, 13(1)48-63

Puppim de Oliveira, J.A., Balaban, O., Dolla, C.N.H., Moreno-Peñaranda, R., A.Gasparatos, A., Iossifova, D. and Suwa, A. (2011), Cities and biodiversity: Perspectives and governance challenges for implementin the convention on biological diversity (CBD) at the city level. Biological Conservation, 144(5), 1302-1313

Schewenius, M., McPhearson, T and Elmqvist, T. (2014), Opportunities for Increasing Resilience and Sustainability of Urban Social-Ecological Systems: Insights from the URBES and the Cities and Biodiversity Outlook Projects (AMBIO), A Journal of the Human Environment, 43(1), 434-444

Rebele, F. (1994), Urban ecology and special features of urban ecosystems, Global Ecology and Biogeography Letters, 4(6), 173-187

Reed, B. (2007), Shifting from 'sustainability' to regeneration, Building Research and Information, 35(6), 674-680

SIDA (2016), Urban Development: Biodiversity and Ecosystems, Stockholm: Swedish International Development Cooperation Agency (SIDA)

Snep, R. P., Opdam, P. F., Baveco, J.M., Wallis De Vries, M.F., Timmermans, W., Kwak, R.G. and Kuypers, V. (2006), How peri-urban areas can strengthen animal populations within cities: A modeling approach, Biological Conservation,127(1), 345-355

Swain, J. and French, S. (2004), Researching Together: A participatory approach. In French S. and Sim, J. (eds.) Physiotherapy: A psychosocial approach (3rd ed.), Oxford: ButterworthHeinemann

UK Green Building Council (2009), Biodiversity and the Built Environment, A report by the UK-GBC Task Group, London: UK Green Building Council 
UNDP (2016), Biodiversity and The 2030 Agenda For Sustainable Development, Technical Note, The Convention on Biological Diversity, Secretariat of the Convention on Biological Diversity, Montreal, Quebec, United Nations Development Programme (UNDP), available at: https://www.cbd.int/development/doc/biodiversity-2030-agenda-technical-note-en.pdf

UNECE (2018), Biodiversity at the Heart of Sustainable Development, Regional Forum on Sustainable Development for the UNECE Region, Geneva, 1 March 2018, Convention on Biological Diversity (CBD) Secretariat and UN Environment, United Nations Economic Commission for Europe(UNECE)

UNEP (2011), United Nations Decade on Biodiversity: Living in Harmony with Nature, UNEP Convention on Biological Diversity, available at:

https://www.cbd.int/undb/media/factsheets/undb-factsheets-en-web.pdf, Accessed on 20/ $10 / 17$

UN (1992), Convention on biological diversity, United Nations Conference on Environment and Development, Rio de Janeiro, United Nations, online, available at: https://www.cbd.int/doc/legal/cbd-en.pdf, Accessed on 20/10/17

UN (2015), Transforming our world: the 2030 Agenda for Sustainable Development, Resolution adopted by the General Assembly, Seventieth session on 25 September 2015, $\mathrm{A} / \mathrm{RES} / 70 / 1$

Vergnes, A., Kerbiriou, C. and Clergeau, P. (2013), Ecological corridors also operate in an urban matrix: A test case with garden shrews, Urban Ecosystems, 16(1), 511-525

Willmott Dixon (2010), The Impacts of Construction and the Built Environment, Briefing Note 33, version 1, London

Woodall, R. and Crowhurst, D. (2003), Biodiversity Indicators for Construction Projects, London: Construction Industry Research and Information Association (CIRIA)

Zari, P. M (2012), Ecosystem services analysis for the design of regenerative urban built environments, Building Research Information, 40(1), 54-64

Zari, M. P. (2014), Ecosystem Services Analysis in Response to Biodiversity Loss Caused by the Built Environment, Surveys and Perspectives Integrating Environment and Society

(S.A.P.I.EN.S), 7 (1), 1-14 